\title{
Efektivitas Pemberian Biskuit Ikan Teri Terhadap Peningkatan Kadar Hemoglobin Pada Remaja Putri
}

\section{Effectiveness of Providing Anchovy Biscuits on Increasing Hemoglobin Levels in Young Girls}

\author{
Kiki Uniatri Thalib', Suryani As'ad ${ }^{2}$, Healthy Hidayanti ${ }^{3}$, Mardiana Ahmad ${ }^{4}$, \\ Andi Nilawati Usman ${ }^{5}$ \\ 1,4,5 Jurusan Kebidanan, Sekolah Pascasarjana Universitas Hasanuddin \\ ${ }^{2}$ Departemen gizi, Fakultas Kedokteran Universitas Hasanuddin \\ ${ }^{3}$ Jurusan Kesehatan Masyarakat, Fakultas gizi, Universitas Hasanuddin \\ Email Address: kikiuniatri.thalib93@gmail.com
}

\begin{abstract}
ABSTRAK
Anemia merupakan masalah kesehatan utama di seluruh dunia maupun di Indonesia. Remaja Putri lebih rentan terkena anemia karena masa pertumbuhan yang cepat sehingga membutuhkan zat gizi yang lebih tinggi termasuk zat besi dan protein. Penelitian ini bertujuan untuk mengetahui bagaimana Efek pemberian biscuit ikan Teri (Stolephorus sp) terhadap peningkatan kadar Hemoglobin pada Remaja Putri di SMK 01 Rangas Kabupaten Mamuju. Jenis penelitian yang digunakan adalah penelitian kuantitatif dengan desain Penelitian yang digunakan yaitu Quasi Experiment dengan rancangan Nonequaivalent Control Group design dimana terdapat 2 kelompok uji yakni kelompok kontrol dan kelompok intervensi. Populasi penelitian adalah seluruh Remaja Putri kelas XI SMK 01 Rangas Kabupaten Mamuju. Penelitian ini di lakukan pada bulan Januari - April 2020. Tekhnik pengambilan sampel dengan menggunakan purposive sampling dengan memperhatikan beberapa kriteria inklusi dan ekslusi sehingga diperoleh sampel sebanyak 60 orang. Sampel dibagi menjadi 2 kelompok yakni 30 kelompok intervensi dan 30 kelompok kontrol. Kelompok intervensi diberikan biskuit Ikan Teri sedangkan kelompok kontrol di berikan placebo biskuit. Pengukuran kadar Hemoglobin dilakukan 2 kali yakni sebelum dan setelah intervensi. Intervensi dilakukan selama 12 minggu. Data dianalisis dengan menggunakan uji Wilcoxon dan Uji Man-Whitney Hasil dari penelitian ini menunjukkan bahwa dari hasil uji statistic didapatkan nilai $(p=0.001, p<0.05)$ yang berarti ada pengaruh pemberian Biskuit Ikan Teri terhadap peningkatan kadar Hemoglobin Remaja Putri di SMK 01 Rangas Kabupaten Mamuju.Hasil analisis data dan hasil evaluasi pada intervensi Biskuit Ikan Teri, yaitu ada perbedaan peningkatan kadar Hemoglobin setelah di berikan intervensi Biskuit Ikan Teri pada Remaja Putri di SMK 01 Rangas Kabupaten Mamuju.
\end{abstract}

Kata Kunci: biskuit ikan Teri,Hemoglobin, Remaja Putri

\section{ABSTRACT}

Anemia is a major health problem throughout the world and in Indonesia. Young women are more prone to developing anemia because of their rapid growth period, so they need higher levels of nutrients including iron and protein. This study aims to determine how the effect of giving anchovy biscuits (Stolephorus sp) on the increase in hemoglobin levels in young women at SMK 01 Rangas, Mamuju Regency. This type of research is quantitative research. The research design used is a Quasi Experiment with a Nonequaivalent Control Group design where there are 2 test groups, namely the control group and the intervention group. The study population was all female adolescents class XI SMK 01 Rangas Mamuju Regency. This research was conducted in January - April 2020. The sampling technique used purposive sampling by paying attention to several inclusion and exclusion criteria in order to obtain a sample of 60 people. The sample was divided into 2 groups, namely 30 intervention groups and 30 control groups. The intervention group was given anchovy biscuits while the control group was given placebo biscuits. Hemoglobin levels were measured twice, before and after the intervention. The intervention was carried out for 12 weeks. The data were analyzed using the Wilcoxon test and the Man-Whitney test. The results of this study indicate that the statistical test results obtained a value $(p=0.001, p<0.05)$, which means that there is an effect of anchovy biscuits on increasing hemoglobin levels for young women at SMK 01 Rangas. Mamuju District. The results of data analysis and evaluation results on the anchovy biscuit intervention, 
namely there is a difference in the increase in hemoglobin levels after giving the anchovy biscuit intervention to young women at SMK 01 Rangas, Mamuju Regency.

Keywords: Anchovy Biscuits, Hemoglobin, Young Women

\section{PENDAHULUAN}

Masa Remaja adalah tahap transisi dari siklus hidup manusia dimana mereka meghadapi berbagai jenis perubahan fisiologi. Masa Remaja adalah periode kematangan fisiologis, psikologis dan social dari masa kanak kanak ke dewasa. (Kankana De, (2016)

Anemia merupakan salah satu masalah kesehatan di seluruh dunia terutama di Negara berkembang, menurut World Health Organization prevalensi Anemia dunia berkisar 40 88\% sedangkan angka kejadian anemia pada Remaja Putri di Negara - negara berkembang sekitar $53,7 \%$ dari semua Remaja putri, anemia sering menyerang remaja putri disebabkan karena keadaan stress, haid atau terlambat makan dan factor kekurangan Asupan gizi.

Berdasarkan data Riset Kesehatan Dasar (Riskesdas) Tahun 2013, jumlah penderita Anemia di Indonesia terdiri dari 26,4\%anak-anak, 12,4\% laki-laki usia 13-18 tahun, 16,6 \% laki-laki di atas 15tahun, 22,7\% perempuan usia 13-18 tahun, 22,7\% wanita usia 15-49 Tahun dan 37,1 \% pada ibu hamil.Prevalensi anemia gizi besi menurut data yangdikeluarkan Depkes RI kelompok wanita usia subur $26,4 \%$.

Menurut data yang diperoleh dari Puskesmas Rangas Kabupaten Mamuju Prevalensi Anemia di SMK 01 Rangas Kabupaten Mamuju pada Remaja Putri sebesar $27 \%$ dari Tingkat Anemia, $0.05 \%$ tergolong Anemia sangat berat, $3 \%$ yang mengalami Anemia sedang (Moderate) dan 24\% tergolong Anemia ringan. Dari hasil Survei peneliti di SMK 01 Rangas merupakan sekolah yang belum direalisasikannya Program Pemerintah dengan pemberian TTD pada Remaja Putri selain itu SMK 01 Rangas Menurut data yang diperoleh dari Puskesmas Rangas Kabupaten Mamuju Prevalensi Anemia di SMK 01 Rangas Kabupaten Mamuju pada remaja putri sebesar $27 \%$, ditinjau dari tingkat keparahan Anemia, 0,5\% tergolong Anemia sangat berat, 3\% yang mengalami Anemia sedang (moderate), dan 24\% tergolong Anemia ringan. Dari hasil Survei Peneliti SMK 01 Rangas merupakan sekolah yang belum direalisasikannya program pemerintah dengan pemberian TTD pada remaja 
selain itu SMK 01 Rangas merupakan Sekolah yang berada di pinggir kota dengan jumlah siswa dan siswi sebanyak 750 di antaranya siswi putri sebanyak 350 orang dan siswa putra sebanyak 400 orang.

Kesehatan seorang Remaja Puteri sebagai calon seorang ibu sekaligus sebagai penerus bangsa perlu menjadi perhatian utama. Hal ini berkaitan juga dengan target SDGs yang masih memerlukan upaya keras untuk pencapaiannya yaitu kesehatan ibu melahirkan, dalam siklus hidup, tahap masa Remaja terutama Remaja putri sangat penting karena pada masa ini terjadi proses tumbuh kembang sehingga bila proses ini berlangsung secara optimal akan menghasilkan Remaja putri yang sehat dan pada akhirnya akan menghasilkan calon ibu yang sehat pula.

$$
\text { Berbagai upaya dalam }
$$
pencegahan Anemia contohnya di beberapa Negara lain memiliki beberapa pedoman dalam pencegahan Anemia salah satunya penganjuran langkah langkah diet dan berfokus pada perubahan kebiasaan diet terhadap makanan dengan kandungan zat besi yang tinggi dan ketersediaan hayati zat besi yang tinggi misalnya di Inggris dan Warles oleh pusat Kolaborasi Nasional untuk Kesehatan perempuan dan Anak selain itu di Negara lain contohnya Amerika serikat menganjurkan perempuan untuk mengkonsumsi zat besi Oral (Centers for disease control and prevention, 2012)

Menurut penelitian Sujam gautam et,al (2019) menyebutkan bahwa factor - factor yang mempengaruhi kejadian Anemia adalah Usia, etnisitas, BMI, pendidikan dan hasil penelitian ini berbeda secara signifikan. Penelitian di India yang dilakukan oleh Thomas, Chandra, Sharma, Jein dan Pemde (2015) menemukan bahwa defesiensi zat besi serta menstruasi berhubungan dengan kejadian anemia pada Remaja.

Dari hasil penelitian di atas menyimpulkan bahwa penyebab Anemia karena defesiensi zat besi dan salah satu makanan yang kaya akan Kandungan zat besi adalah ikan teri. Setiap 100 gram tepung ikan teri terdapat $3.9 \mathrm{mg}$ zat besi. Kandungan zat besi yang tinggi akan mencegah anemia dan memperlancar kerja darah merah dalam mengalirkan oksigen dan sari-sari makanan ke seluru tubuh. Dengan manfaat yang cukup, teri cukup di rekomendasikan untuk di makan dengan jumlah yang tepat sesuai dengan kebutuhan nutrisi harian. 
Penelitian oleh zou Y et,al (2017) dengan judul karakterisasi factor kunci dari daging ikan Teri Engraulis japonicas dalam peningkatan Nanopartikel Mediated penyerapan serapan besi Non -Heme didapatkan bahwa daging Ikan Teri terbukti meningkatkan penyerapan zat besi nonheme melalui mekanisme mediated oxyhydroxide nanoparticle (FeONP) menghasilkan efisiensi regenerasi hemoglobin pada tikus anemia.

Terdapat beberapa penelitian lain tentang Ikan Teri yang dilakukan oleh peneliti sebelumnya diantaranya oleh Armida dkk (2017) pengaruh pemberian biscuit dengan penambahan tepung Ikan Teri terhadap berat badan dan kadar kalsium Anak balita KEP umur 12 - 24 bulan di kecamatan Banggae Kabupaten Mamuju mendapatkan hasil ada pengaruh pemberian biscuit dengan penambahan Tepung ikan Teri terhadap peningkatan Berat badan dan kadar Kalsium (Ca) pada Anak Balita KEP umur $12-24$ bulan.

Dari hasil penelitian oleh Eka (2015) Universitas semarang terhadap uji penerimaan Tepung Ikan teri mendapatkan Hasil yaitu Terdapat pengaruh konsentrasi tepung ikan teri(Stolephorus $s p$ ) pada pembuatan kudapan PMT balita terhadap sifat organoleptik warna, rasa, aroma dan tekstur, berdasarkan uji tingkat kesukaan panelis dapat disimpulkan bahwa konsentrasi penambahan tepung ikan teri 25\% (F3) memberikan tingkat kesukaan yang baik dalam seluruh aspek.Pemberian biscuit ikan Teri (Stolephorus Sp) : biscuit atau tepung ikan teri Stolephorus $\mathrm{Sp}$ yang telah melalui proses uji Laboratorium dan uji penerimaan pada penelitian sebelumnya yang akan diberikan pada Remaja putri guna memenuhi kecukupan gizi khususnya protein dan zat besi agar dapat meningkatkan kadar Haemoglobin dan Status Gizi.

Tepung ikan Teri merupakan salah satu produk pengolahan hasil sampingan ikan yang sampai saat ini belum di manfaatkan secara maksimal terutama untuk bahan pangan. Pembuatan tepung ikan berbahan dasar ikan teri dapat menjadi suatu bentuk alternatif bahan pangan. Penggunaan tepung ikan Teri sebagai bahan substitusi tepung terigu pada pembuatan biskuit merupakan salah satu alternatif penggunaan yang menjanjikan terutama dari segikualitas gizi. Mervina et al, 2012 
Sebelum dilakukan Intervensi pada Responden Biscuit ikan teri telah di uji laboratorium Makassar dengan hasil 100 gr biscuit ikan Teri mengandung zat gizi yang cukup lengkap seperti lemak, protein, zat besi dan kalsium. Kandungan zat pada biskuit ikan Teri cukup tinggi dengan jumlah energi 277 kkal, protein sekitar $60 \mathrm{~g}$ per $100 \mathrm{~g}$, zat besi 1.40 per 100 gram dan lemak 9.71 per 100 g (Balai besar Laboratorium Kesehatan Makassar)

Berdasarkan uraian di atas peneliti tertarik melakukan penelitian untuk mengetahui dan mengkaji lebih dalam bagaimana Efektivitas pemberian biscuit ikan teri terhadap peningkatan kadar Hemoglobin pada Remaja Putri di SMK 01 Rangas Kabupaten Mamuju.

\section{METODE PENELITIAN}

Jenis penelitian yang digunakan adalah "Quasiexperimental" dengan rancangan "Nonequivalent Control group Design" dimana pada desain ini menggunakan kelompok eksperimen maupun kelompok kontrol tidak dipilih secara random (Sugioyono, 2018)

Adapun jumlah Populasi dalam penelitian ini sebanyak 110 orang Remaja Putri SMK 01 Rangas Kabupaten Mamuju sedangkan Jumlah
Sampel sebanyak 60 dengan dengan memenuhi kriteria inklusi;

1. Remaja putri Kelas $2 \mathrm{SMK}$

2. Tidak ada Riwayat penyakit Infeksi

3. Siklus menstruasi Normal

Bersedia menjadi Responden

Kriteria eksklusi

1. Remaja diluar wilayah kerja Puskesmas Rangas

2. Remaja yang tidak bersedia menjadi responden

Penelitian ini telah dilakukan di SMK 01 Rangas Kabupaten Mamuju Provinsi Sulawesi Barat pada bulan Januari-April 2020.

Pengumpulan data dilakukan oleh peneliti dan di bantu oleh 2 orang guru wali kelas XI SMK 01 Rangas dan menggunakan pre-post tested kuesioner. Pengambilan data kadar Hemoglobin dengan melakukan pengambilan darah sebelum intervensi dengan menggunakan alat Hemocu dan di ukur kembali setelah pemberian intervensi.

Data faktor determinan serta karakteristik sampel diolah dengan menggunakan SPSS for windows 24. Untuk menguji homegenitas karakteristik responden dilakukan test of homogeneity of variance. Untuk menilai pengaruh biscuit ikan Teri terhadap Hemoglobin digunakan analisis. Uji 
wilcoxon dan Uji Man-Whitney

\section{HASIL DAN PEMBAHASAN}

\section{a. Analisis univariat}

Tabel 1.1. Distribusi karakteristik responden

\begin{tabular}{cccc}
\hline \multirow{2}{*}{ Karakteristik } & \multicolumn{2}{c}{ Mean \pm SD } & \multirow{2}{*}{ P value } \\
\cline { 2 - 3 } & & & \\
\hline $\begin{array}{c}\text { Pendidikan orang } \\
\text { Tua (n\%) }\end{array}$ & $27(90)$ & $28(93.33)$ & 0.640 \\
Tinggi $(\geq$ SMA) & $3(10)$ & $2(6.66)$ & \\
Rendah $(<$ SMA) & & & \\
Pendapatan & $3486666.67 \pm 1365772.065$ & $3780000 \pm 1257364.512$ & 0.166 \\
$($ Rp, Mean \pm SD) & & & \\
\hline
\end{tabular}

\section{b. Bivariat}

Berdasarkan Tabel 1.1. diatas memperlihatkan karakteristik responden pada kelompok kontrol dan intervensi. Umur responden antara kelompok kontrol dan kelompok intervensi memiliki varians data yang homogen atau relative sama dengan rata-rata remaja berusia 17 tahun. Berdasarkan berat badan responden menunjukkan varians data yang homogen antar kelompok meskipun rata-rata berat badan remaja dikelompok intervensi lebih kecil dari rata-rata berat badan remaja di kelompok kontrol. Jika dilihat dari tinggi badan, antara kelompok kontrol dan kelompok intervensi memiliki tinggi badan yang heterogen atau beragam dengan rata-rata tinggi badan remaja di kelompok kontrol berkisar $151 \mathrm{~cm}$ sementara remaja di kelompok intervensi berkisar $149 \mathrm{~cm}$. Tabel 1.1 juga menunjukkan bahwa sebagian besar responden untuk kedua kelompok memiliki kategori pendidikan orang tua yaitu pada kelompok intervensi sebesar $90 \%$ dan pada kelompok kontrol sebesar $93.33 \%$ dimana setelah diuji analisis mendapatkan nilai $p=0.640$, dimana $p$ > 0.05 yang berarti kedua kelompok memiliki perbedaan. Selanjutnya untuk kategori pendapatan orang tua responden pada kelompok intervensi memiliki ratarata pendapatan sebesar Rp. 3.780.000, sedangkan pada kelompok kontrol sebesar Rp. 3.486.666, pada kedua kelompok cenderung memiliki karakteristik pendapatan orang tua yang >UMR kota Mamuju Rp. 2.500.000 dan 
setelah diuji analisis didapatkan nilai $p=$ kedua kelompok memiliki pendapatan 0.166 , dimana $p>0.05$ yang berarti setara namun tidak signifikan

Tabel 1.2 perbedaan kadar Hemoglobin Remaja sebelum dan setelah perlakuan pada kelompok intervensi dan kelompok kontrol

\begin{tabular}{|c|c|c|c|c|c|}
\hline \multirow{2}{*}{ Hemoglobin } & \multirow{2}{*}{$\mathbf{N}$} & \multicolumn{2}{|c|}{ Mean \pm SD } & \multirow{2}{*}{$\begin{array}{c}\text { Selisih } \\
\text { Mean }\end{array}$} & \multirow{2}{*}{$P$ value } \\
\hline & & Pre & Post & & \\
\hline Kontrol & 30 & $10.65 \pm 0.58$ & $10.75 \pm 0.75$ & 0,1 & 0.124 \\
\hline Intervensi & 30 & $9.92 \pm 0.77$ & $10.85 \pm 0.91$ & 0,93 & 0.001 \\
\hline$P$ value & & 0.001 & 0.354 & 0.001 & \\
\hline
\end{tabular}

${ }^{a}$ Wilcoxon; ${ }^{b}$ Uji Mann-Withney, Sumber: Data Primer, 2020

Berdasarkan data pada Tabel 1.2 setelah dilakukan uji wilcoxon pada kelompok control tidak terdapat perbedaan pada kadar Hemoglobin sebelum dan setelah di berikan perlakuan dengan nilai selisih mean 0,1 dengan nilai statistic p 0.124 dimana $\mathrm{p}>0.05$ yang berarti tidak ada perbedaan secara pada kadar hemoglobin pada kelompok control sebelum dan setelah diberikan perlakuan.

Pada kelompok intervensi terdapat perbedaan kadar Hemoglobin sebelum dan setelah perlakuan dengan selisih mean 0.93 dengan nilai $\mathrm{p} 0,001$ dimana $\mathrm{p}<0,05$ yang berarti ada perbedaan secara signifikan sebelum dan sesudah di berikan perlakuan.

Terlihat juga Pada tabel $1.2 \mathrm{di}$ atas setelah dilakukan uji kedua kelompok dengan menggunakan uji Man-whitney didapatkan nilai pretest antara kelompok control dan intervensi dengan nilai $\mathrm{p}=0.001$ dimana $\mathrm{p}=<0.05$ yang berarti ada perbedaan secara signifikan antara kedua kelompok pretest sebelum dilakukan perlakuan sedangkan pada nilai posttes kedua kelompok setelah di uji didapatkan nilai $\mathrm{p}=0.034$ dimana $\mathrm{p}=>0.05$ yang berarti tidak ada perbedaan secara signifikan pada hasil postest kedua kelompok namun selisih mean sebelum dan setelah intervensi pada kedua kelompok didapatkan nilai $\mathrm{p}=0.001, \mathrm{p}=<0.05$ yang berarti terdapat perbedaan secara signifikan pada peningkatan antara kelompok intervensi dan kelompok control.

Anemia didefnisikan adalah hasil dari ketidakseimbangan yang berkepanjangan antara asupan dan kebutuhan zat besi didalam tubuh, sejumlah besar factor yang mempengaruhi defesiensi besi adalah konsumsi teh yang sering, social 
ekonomi, sanitasi dan kurangnya makanan yang kaya akan zat besi. Romilda et, al (2014)

Didalam kandungan Biscuit ikan teri yang berbahan dasar Tepung Ikan teri, tepung terigu, lemak nabati tanpa hidrogenasi, gula, susu, telur, kacang kacangan diperkaya oleh vitamin, mineral dan lemak sedangkan Tepung ikan Teri mengandung zat besi, kalsium, protein dan gizi mikro lainnya dengan kandungan yang ada pada ikan teri mampu membentuk Hemoglobin dalam darah sehingga menaikkan kadar Hemoglobin pada Remaja Putri. Ini di buktikan dari Hasil penelitian yang dilakukan Efektivitas pemberian biscuit ikan teri terhadap kadar Hemoglobin pada Remaja dapat kita lihat pada Tabel 1.2 setelah dilakukan uji wilcoxon terdapat perbedaan yang bermakna pada kadar Hemoglobin sebelum dan setelah di berikan perlakuan pada kelompok Intervensi dimana selisih mean 0.93 dengan nilai $\mathrm{p} 0,001$ dimana $\mathrm{p}<0,05$ yang berarti ada perbedaan secara signifikan sebelum dan sesudah di berikan perlakuan sedangkan pada kelompok control juga terjadi peningkatan kadar Hemoglobin sebelum dan setelah di berikan perlakuan namun peningkatannya tidak secara signifikan dimana nilai selisih mean 0,1 dengan hasil nilai uji statistic p 0.124 yang berarti $\mathrm{p}>0.05$ yang berarti tidak ada peningkatan secara signifikan pada kadar hemoglobin sebelum dan setelah diberikan perlakuan pada kelompok kontrol.

Salah factor yang mempengaruhi peningkatan secara signifikan pada kadar Hemoglobin pada Remaja disebabkan nilai gizi zat besi dan protein yang cukup tinggi didalam tepung Ikan Teri dimana Kandungan zat besi yang tinggi akan mencegah anemia dan memperlancar kerja darah merah dalam mengalirkan oksigen dan sari-sari makanan ke seluruh tubuh. Dengan manfaat yang cukup, Ikan Teri cukup di rekomendasikan untuk di makan dengan jumlah yang tepat sesuai dengan kebutuhan nutrisi harian. Ikan teri merupakan lauk mina tinggi protein, seluruh badannya dapat dikonsumsi sehingga memungkinkan penyerapan zat gizi yang maksimal. Protein Teri tersusu atas beberapa macam asam amino esensial (Lasimpala,2014).

Dari hasil penelitian Lina et, al (2019) menemukan bahwa Remaja perempuan yang tidak mengkonsumsi sumber protein hewani setiap hari akan memungkinkan menderita anemia 
(87,5\%) di bandingkan dengan Remaja perempuan yang mengkonsumsi protein hewani setiap hari $(30,3 \%)$ dengan uji statistic di peroleh $\mathrm{P}=<0,001$ yang dapat disimpulkan ada hubungan secara signifikan antara konsumsi protein hewani dengan Anemia Remaja.

Menurut permenkes semua formulasi kandungan besi pada Ikan Teri telah memenuhi syarat dengan kisaran 4,04-5,32 mg/100g. semakin meningkat subtitusi tepung ikan Teri maka kandungan besi cookies semakin tinggi. Hal tersebut karena kandungan besi yang tinggi pada tepung Ikan Teri dan besi terikat dengan struktur protein pada bahan makanan yang tidak mudah hilang karena panas, cahaya dan perbedaan $\mathrm{PH}$. Substitusi tepung ikan Teri dapat meningkatkan kandungan besi sebesar 0,27 - 0,54 mg pada tiap formulasi. Besi pada Ikan Teri termasuk kedalam jenis besi heme yang lebih mudah diabsorbsi tubuh dibandingkan dari sumber non heme sehingga berkontribusi banyak untuk meningkatkan asupan besi.

Kebutuhan zat besi pada Remaja sangat meningkat terutama pada saat menstruasi sehingga untuk mencegah terjadinya Anemia saat menstruasi diperlukan zat besi tambahan seperti pemberian biscuit Ikan Teri selain itu kandungan zat besi didalam Biskuit Ikan Teri merupakan zat mikronutrien penting yang dibutuhkan tubuh untuk membantu membangun sel darah dan berfungsi membantu sel-sel darah membawa oksigen yang dibutuhkan untuk energy, didalam kandungan biscuit ikan teri mengandung zat gizi yang cukup dan lengkap seperti lemak, protein, zat besi dan kalsium dapat membantu Remaja dalam mencegah Anemia terutama pada saat menstruasi.

Dengan nutrisi yang baik maka kadar Hemglobin pada Remaja juga baik, nutrisi Remaja sangat penting untuk pertumbuhan dan perkembangan yang tepat. Nutrisi suboptimal dapat berkontribusi pada pertumbuhan yang terhambat dan defesiensi zat besi adalah salah satu dari 10 penyebab utama Anemia. Rehana et, al (2016)

Sejalan dengan Penelitian oleh Thomas et, al (2015) di India menemukan bahwa defisiensi zat besi berhubungan dengan kejadian Anemia pada Remaja pada saat menstruasi. Menurut kementrian kesehatan melalui angka Kecukupan gizi (AKG) 2013 untuk mencukupi kebutuhan zat besi remaja putri menyarankan Remaja putri mengkonsumsi zat besi sesuai usia dimana pada usia 10-12 tahun sebesar 20 
$\mathrm{mg} /$ hari, usia 13-15 tahun sebesar 26 $\mathrm{mg} /$ hari pada usia 16-18 tahun sebesar $26 \mathrm{mg} / \mathrm{hari}$. Pentingnya zat besi yang cukup untuk Remaja guna memenuhi kebutuhan saat menstruasi dan mencegah anemia pada Remaja.

Selain zat besi yang cukup tinggi pada biskuit ikan teri juga kandungan protein yang cukup baik didalam biscuit ikan teri menurut penelitian Rahmawati et.al (2019) menunjukkan bahwa kandungan protein cookies semakin meningkat dengan semakin besarnya tepung ikan teri yang di substitusikan mulai dari F0 hingga F3 peningkatan kandungan protein ikan Teri (48,8 g/100 g) yang lebih tinggi di bandingkan pada tepung terigu $(9 g / 100 g)$. subtitusi tepung ikan teri dapat meningkatkan kandungan protein cookies sebesar 0,92-2,37 g pada setiap formulasi hasil tersebut juga sejalan dengan penelitian Hestin $R$ mengenai cookies yang disubtitusikan tepung ikan Teri dan tepung tempe dimana interaksi tepung ikan Teri dan tepung tempe berpengaruh protein pada cookies.

Selain itu karakteristik pendidikan orang tua akan menjadi factor yang tidak langsung mempengaruhi kadar Hemoglobin Remaja dikarenakan tingkat pendidikan berkaitan langsung dengan tingkat pengetahuan orang tua terhadap asupan gizi yang harus dipenuhi remaja dalam setiap harinya dengan pemahaman yang baik maka kebutuhan gizi akan tercukupi dengan baik sehingga mempengaruhi peningkatan kadar Hemoglobin pada remaja. Semakin tinggi pendidikan orang tua maka tingkat pengetahuan dan perilaku orang tua akan memenuhi kebutuhan gizi apa saja yang diperlukan seorang anak Remaja untuk meningkatkan kadar Hemoglobin Remaja sebab pendidikan orang tua sangat penting dalam keluarga baik dalam segi mendidik anak maupun mengatur pola makan anak.

Sejalan dengan penelitian Simamora (2018) menambahkan bahwa tingkat pendidikan merupakan salah satu sebab mendasar yang dapat mengakibatkan kejadian Anemia. Di dalam penelitian Aedh, etal (2019) juga menemukan bahwa tingkat pendidikan ibu secara bermakna dikaitkan dengan Anemia dan di anggap sebagai salah satu penentu penting pada kasus Anemia.

selain itu factor yang lain menyebabkan Anemia menurut penelitian Aed, et.al (2019) menyebutkan bahwa hubungan yang signifikan terjadinya anemia adalah 
defesiensi besi dan seringnya asupan minuman soda dan produk susu yang menghambat penyerapan besi, hasil yang disimpulkan sejalan dengan penelitian oleh Ashry et, al mengemukakan socia ekonomi tidak terkait secara signifikan dengan Anemia meskipun banyak penelitian yang menunjukkan bahwa memang ada hubungan yang kuat dan signifikan antara pendapatan kelurga dengan Anemia defesiensi zat besi mereka juga berpendapat pendapatan rendah sering berkorelasi dengan akses terbatas ke berbagai makanan yang menyebabkan Anemia.

Sehingga dengan adanya pemberian Biscuit Ikan Teri dapat dikonsumsi Remaja Putri dalam mencegah terjadinya Anemia. Selain nilai gizi yang cukup baik yang terkandung pada Ikan Teri juga ekonomis, praktis dan mudah dikonsumsi kapan saja sebagai cemilan setiap hari.

\section{SIMPULAN DAN SARAN}

Hasil analisis data pada kelompok intervensi Biskuit Ikan Teri yaitu ada perbedaan peningkatan kadar Hemoglobin setelah di berikan intervensi Biskuit Ikan Teri pada
Remaja Putri di SMK 01 Rangas Kabupaten Mamuju.

\section{DAFTAR PUSTAKA}

Anemia defesiensi Besi pada Remaja; Tinjauan Literatur.Romilda castro de Andrade Cairo. DOI 10.3305/ nh.2014.29.6.7245

WHO, "Kemenkes RI Tahun 20152017," no. Idl, pp. 2017-2019, 2017.

Kemenkes, "RISKESDAS 2018: Executive Summary," 2018.

K. Perkantoran Gubernur, J. Abdul Malik Pattana Endeng, K. Simboro Dan Kepulauan, K. Mamuju, S. Barat, and S. Sehat, "Dinas Kesehatan Provinsi Sulawesi Barat V B a C," 2017.

E. A. Hidayati, "Pengaruh Konsentrasi Tepung Ikan Teri (Stolephorus sp) pada Pembuatan Kudapan PMT Balita terhadap Kandungan Protein dan Sifat Organoleptik," Skripsi. Fak. Ilmu Keolahragaan. Univ. Negeri Semarang, pp. 165, 2015.

I. Astrina, "Pengaruh pemberian ikan teri nasi terhadap jumlah osteosit dan kepadatan tulang alveolar rahang bawah pada tikus wistar putih (Rattus norvegicus)," pp. 1-107, 2019.

F. T. Sri Rejeki, Restu Libriani, "KARAKTERISASI FISIK BUBUR BAYI INSTAN BERBAHAN DASAR TEPUNG BERAS MERAH (Oryza nivara) DAN TEPUNG IKAN TERI (Stolephorus)," J. Sains dan 
Teknol. Pangan, vol. 3, no. 5, pp. 1674-1681, 2018.

Intervensi untuk meningkatkan Nutrisi Remaja Tinjauan sistematis dan meta analisis Rehana A.salam. divisi Kesehatan Wanita dan Anak Universitas Aga khan Korachi, Pakistan. Journal of Adolescent Health. Elseveir

Iron defeciency Anemia in Adolescents;a literatur review, Romilda Castro et,al. ISSN 02121611.CODEN

NHOEQ.S.V.R.318

Faktor penentu untuk prevalensi pada Wanita usia Reproduksi di Nepal:bukti Survei Nasional baru-baru ini Tahun 2019.Depatemen Adiministrasi Kesehatan Sekolah pascasarjana universitas Yonsei. DOI.org.//10.1371/Journalpone. 0218288

Faktor - faktor yang berhubungan dgan status gizi Remaja usia Tahun di indonesia. Ratna Indra sari et,al. departemen Kesehatan Masyarakat Universitas Indonesia. DOI 10.18502/kls v4i10.3806

Faktor - faktor yang mempengaruhi Status gizi pada gadis Remaja di Riyadh/Saudi Arabia. Maha Al Turki.

ASST.Profesor.COAMS.KSAU. -HS,KAMS

KAIMRC.NGHA,Riyadh,KSA ISSN2454-6348 DOI 10.26479/2018.0406.20

E. Priyanti, "Studi Lama Waktu Pengeringan Dihubungkan dengan Penurunan Berat dan
Laju Pengeringan Ikan Teri (Stolephorus sp.)," Biomedika, vol. 9, no. 1, pp. 21-25, 2016.

Y Zou, "Karakterisasi faktor kunci dari daging ikan teri engraulis japonicas dalam peningkatan nanopartikel mediated penyerapan serapan gizi non heme," J. Nutr. Coll., 2017.

Armida, "Pengaruh pemberian biscuit dengan penambahan tepung ikan teri terhadap berat badan dan kalsium anak balita KEP umur 12-24 bulan dikecamatan Banggae Kabupaten Majene. Fakultas Kesehatan Masyarakat Universitas Hasanuddin Makassar,” 2017.

B. Setyawati and A. Syauqy, "Perbedaan Asupan Protein, Zat Besi, Asam Folat, Dan Vitamin B12 Antara Ibu Hamil Trimester Iii Anemia Dan Tidak Anemia Di Puskesmas Tanggungharjo Kabupaten Grobogan," J. Nutr. Coll., vol. 3, no. 1, pp. 228-234, 2014.

A. . Hoffbrand and P. A. H. M. J..E Petit, Kapita Selekta Hematologi, vol. 4. 2008.

P. D.L and G. J.F, "An Introductory," Pediatr. Nurs., 2014.

Pengaruh sosial Ekonomi terhadap status gizi gadis Remaja pedesaan. Universitas Vidyasagor. Medinipur. Benggala Barat India DOI 10.4172/2332.0915.1000168, 2016

Kandungan gizi dan daya Terima Cookies berbasis Tepung Ikan 
Teri (Stolephorus Sp) sebagai PMT-P untuk Balita Kurang Gizi. Rahmawati ramadhan. Fakultas Kedokteran Universitas Di penogoro. Volume 8 no 4 Tahun 2019 ISSN:2337-6236;EISSN : 2622-884x

Studi banding tentang status gizi Remaja

$\begin{array}{lrr}\text { putri dari } & \text { berbagai } & \begin{array}{r}\text { Daerah } \\ \text { pedesaan }\end{array} \\ \text { Benggal } & \begin{array}{r}\text { Barat. } \\ \text { Departemen }\end{array} \\ \text { Antropologi } & \text { pedesaan } \\ \text { Vidjasagor De Anthropologitas } \\ \text { DOI } \\ \text { 4172/2332.0915.1000173.2016 }\end{array}$

putri dari berbagai Daerah Departemen pedesaan Antropologi Universitas DOI 4172/2332.0915.1000173.2016 